WALDEMAR KOZŁOWSKI

Szkoła Główna Gospodarstwa Wiejskiego

$w$ Warszawie

EWA MATCZAK

Instytut Badań Edukacyjnych

w Warszawie

\title{
ASPIRACJE EDUKACYJNE RODZICÓW I DZIECI A OSIĄGNIĘCIA SZKOLNE
}

Aвstract. Kozłowski Waldemar, Matczak Ewa, Aspiracje edukacyjne rodziców i dzieci a osiągnięcia szkolne [Educational Aspirations of Parents and Children and School Achievement]. Studia Edukacyjne nr 47, 2018, Poznań 2018, pp. 313-328. Adam Mickiewicz University Press. ISSN 1233-6688. DOI: 10.14746/ se.2018.47.19

Numerous studies have found an association of educational aspirations of parents and children with their school achievement. The study verifies these relationships for about 5,000 people, a representative sample of parents and their children-primary school students. Three aspects of aspirations were taken into account: the maximum (desired), the feasible (expected) and the lowest acceptable. Expected aspirations of parents are mostly related to the achievements of children; students' achievements are associated with both their feasible and maximum aspirations. There was a significant relationship between aspirations of parents and children and a strong correlation between parental aspirations and their level of education.

Key words: educational aspirations, parents, children, educational achievement

\section{Zarys problematyki}

Badania jednoznacznie pokazują, że aspiracje i oczekiwania rodziców dotyczące edukacji dzieci są silnie związane $\mathrm{z}$ ich osiągnięciami w uczeniu się, zarówno wtedy, gdy kryterium osiągnięć stanowią wyniki testów, jak i wskaźniki osiągnięć, typowe dla krajów anglosaskich ${ }^{1}$. Co ważne, efekty ta-

${ }^{1}$ A.D. Benner, R.S. Mistry, Congruence of mother and teacher educational expectations and low-income youth's academic competence, Journal of Educational Psychology, 2007, 1, s. 140-153; M.P. 
kie występują przy wyeliminowaniu innych czynników, głównie związanych ze społeczną pozycją rodziców.

Chociaż aspiracje i oczekiwania bywają określane inaczej, nierzadko terminy te używane są zamiennie ${ }^{2}$. Niekiedy dokonuje się niezależnego pomiaru obu zjawisk, lecz w celach analitycznych tworzy jeden wskaźnik3. Zabieg taki opiera się na pozytywnym związku oczekiwań z aspiracjami, który występuje, kiedy oczekiwania dotyczą wykształcenia, jakie w przyszłości może uzyskać dziecko ${ }^{4}$. Niekiedy oczekiwania dotyczą szkolnych osiągnięć, co wprowadza dodatkową niejasność, ponieważ część omówionych wyżej zależności nie wiąże się $\mathrm{z}$ aspiracjami.

Na przykład, Gregg, Macmillan i Washbrook wykazali, że aspiracje matek 9-letnich dzieci są najsilniejszym czynnikiem związanym z ich osiągnięciami szkolnymi ${ }^{5}$. Halle i inni uzyskali umiarkowanie silną zależność pomiędzy oczekiwaniami rodziców dotyczącymi osiągnięć w uczeniu się a ocenami z matematyki oraz czytania ${ }^{6}$. Strand ${ }^{7}$ stwierdził, że dzieci, których rodzice mają wysokie aspiracje edukacyjne (a także posiadające komputer oraz pozaszkolne wsparcie w uczeniu się) mają wysokie osiągnięcia w uczeniu się,

Neuenschwander i in., Parents'expectations and students' achievement in two western nations, International Journal of Behavioral Development, 2007, 31, s. 594-602; K. Singh i in., The effects of four components of parental involvement on eighth-grade student achievement: Structural analysis of NELS88 data, School Psychology Review, 1995, 24, s. 299-317; M. Zhan, Assets, parental expectations and involvement, and children's educational performance, Children and Youth Services Review, 2006, 28, s. 961-975; E. Flouri, Raising expectations, The Psychologist, 2006, 19(11), s. 664-669; S. Gill, A.J. Reynolds, Educational expectations and school achievement of urban African American children, Journal of School Psychology, 1999, 37, s. 403-424; S.F. Seyfried, I. Chung, Parent involvement as parental monitoring of student motivation and parent expectations predicting later achievement among African American and European American middle school age students, Social Work with Multicultural Youth, 2002, 11, s. 109-131.

${ }^{2}$ X. Fan, M. Chen, Parental involvement and students' academic achievement: A meta analysis, Educational Psychology Review, 2001, 13, s. 1-22; L. Juang, R.K. Silbereisen, The relationship between adolescent academic capability beliefs, parenting, and school grades, Journal of Adolescence, 2002, 25, s. 3-18; W. Mau, Educational planning and academic achievement of middle school students: A racial and cultural comparison, Journal of Counseling and Development, 1995, 73, s. 518-527.

3 A. Bandura i in., Mechanism of moral disengagement in the exercise of moral agency, Journal of Personality and Social Psychology, 1996, 71, s. 364-374.

${ }^{4}$ A.D. Benner, R.S. Mistry, Congruence of mother and teacher educational expectations, s. 140153; S. Catsambis, Expanding knowledge of parental involvement in children's secondary education: connections with high schools seniors' academic success, Social Psychology of Education, 2001, 5, s. $149-177$.

${ }^{5}$ Za: A. Goodman, P. Gregg, E. Washbrook, Children's educational attainment and the aspirations, attitudes and behaviours of parents and children through childhood in the UK, Longitudinal and Life Course Studies, 2011, 2, s. 1-18.

${ }_{6}^{6}$ T.G. Halle, B. Kurtz-Costes, J.L. Mahoney, Family influences on school achievement in low-income, African American children, Journal of Educational Psychology, 1997, 89, s. 527-537.

7 S. Strand, Minority ethnic pupils in the longitudinal study of young people in England (LSYPE), Department of Children, Schools, and Families: 2007, Research Report 002. 
określane poprzez średnią ocen. Potwierdzając znaczenie aspiracji rodzicielskich, wyniki te sugerują, że ich pozytywny wpływ może wiązać się z działaniami wspierającymi edukację dzieci. Jacob i Harvey ${ }^{8}$ prowadząc badania wśród australijskich uczniów stwierdzili, że oczekiwania rodziców (utożsamiane czasami z aspiracjami) są silnym predyktorem ich osiągnięć w uczeniu się. Analizując dane zebrane w programie NELS, Trusty, Plata i Salazar ${ }^{9}$ otrzymali podobne rezultaty: oczekiwania rodziców oraz ich zaangażowanie w uczenie się dzieci miały największy wpływ na osiągnięcia, przewyższając w tym względzie znaczenie takich czynników, jak status społeczno-ekonomiczny (SES), samoocena dzieci oraz ich uprzednie doświadczenia szkolne.

Badania wykazują także, że rodzicielskie oczekiwania i aspiracje w istotny sposób pozwalają przewidywać oczekiwania uczniów ${ }^{10}$.

Wśród badaczy występuje zgodność poglądów, iż także oczekiwania dzieci są w silnym stopniu związane z osiągnięciami szkolnymi oraz ich zachowaniem się na terenie szkoły ${ }^{11}$. Efekt taki otrzymali na przykład Khoo i Ainley ${ }^{12}$ rozważając dane australijskiego longitudinalnego sondażu młodzieży (Longitudinal Survey of Australian Youth). Stwierdzili oni, że deklarowane zamiary ukończenia szkoły średniej na początku kształcenia są związane z kontynuacją nauki i dobrymi w niej osiągnięciami w latach późniejszych.

Także badania polskie potwierdzają istnienie związków aspiracji z osiągnięciami. Zależności takie otrzymał na przykład $\mathrm{T}$. Lewowicki ${ }^{13}$ analizując aspiracje licznych, lecz niereprezentatywnych, prób uczniów szkół podstawowych i zestawiając je z ocenami z języka polskiego i matematyki. Silniejsze korelacje dotyczyły języka polskiego $(r=0,56)$ niż matematyki $(r=0,47)-\mathrm{w}$ obu przypadkach są one statystycznie istotne.

Badania nie rozstrzygają kierunku stwierdzanych zależności. Zazwyczaj zakłada się, że aspiracje określają osiągnięcia. Równie zasadne jest jednak

${ }^{8}$ N. Jacobs, D. Harvey, Do parents make a difference to children's academic achievement? Differences between parents of higher and lower achieving students, Educational Studies, 2005, 31, s. $431-448$.

9 J. Trusty, M. Plata, C.F. Salazar, Modeling Mexican Americans' educational expectations: Longitudinal effects of variables across adolescence, Journal of Adolescent Research, 2003, 18, s. 131-153.

10 A.D. Benner, R.S. Mistry, Congruence of mother and teacher educational expectations, s. 140153; K. Goyette, Y. Xie, Educational expectations of Asian American youths: Determinants and ethnic differences, Sociology of Education, 1999, 72, s. 22-36; D. Hossler, F.K. Stage, Family and high school experience influences on the postsecondary educational plans of ninth-grade students, American Educational Research Journal, 1992, 29, s. 425-451; K.M. Jodl i in., Parents' roles in shaping early adolescents' occupational aspirations, Child Development, 2001, 72, s. 1247-1265.

${ }^{11} \mathrm{~S}$. Cheng, B. Starks, Racial differences in the effects of significant others on students' educational expectations, Sociology of Education, 2002, 75, s. 306-327.

12 S. Khoo, J. Ainley, Attitudes, intentions and participation, LSAY research report 41, Australian Council for Educational Research, Melbourne 2005.

${ }^{13}$ T. Lewowicki, Aspiracje dzieci i młodzieży, Warszawa 1987. 
przypuszczenie, że osiągnięcia dziecka kształtują (lub modyfikują) aspiracje rodziców, jak i uczniów. Przemawiają za nim na przykład wyniki badań Goldenberga i innych ${ }^{14}$.

Oprócz kwestii związanych z trudnością określania wpływu i ustalania relacji przyczynowo-skutkowych (analizy korelacyjne nie pozwalają rozstrzygnąć tych kwestii), w badaniach zarysowują się także inne zjawiska dyskusyjne. Po pierwsze, zależności pomiędzy aspiracjami, oczekiwaniami a osiągnięciami nie są jednoznaczne. Część badań ich nie potwierdza. Na przykład, Carpenter II $^{15}$ ustalił, że zarówno aspiracje, jak i oczekiwania latynoskich rodziców zamieszkałych w USA nie są związane ze szkolnymi osiągnięciami ich dzieci. Goldenberg i inni ${ }^{16}$ stwierdzili, że oczekiwania rodziców nie są związane z osiągnięciami dzieci w wieku przedszkolnym, zaś w wieku szkolnym związek taki występuje i stopniowo zyskuje na znaczeniu. Nie ma natomiast analogicznego związku z aspiracjami. Niektóre badania sugerują, że aspiracje rodziców są związane $\mathrm{z}$ osiągnięciami dzieci, lecz w powiązaniu z innymi czynnikami. Marjoribanks ${ }^{17}$ doszedł do wniosku, że osiągnięcia można przewidywać na podstawie statusu społecznego rodziców, ich aspiracji edukacyjnych oraz przynależności etnicznej (dane zebrano na licznej próbie rodzin australijskich).

Kwestia druga dotyczy rozbieżności pomiędzy aspiracjami edukacyjnymi a zdobytym wykształceniem, określanej jako paradoks „,aspiracje-osiągnięcia” lub mianem luki pomiędzy aspiracjami a osiągnięciami (aspiration-attainment gap). Badania w wielu krajach, realizowane pod koniec ubiegłego wieku, rejestrowały wysoki wzrost aspiracji edukacyjnych rodziców i dzieci (określany często jako nierealistyczny), któremu nie towarzyszył równie duży przyrost osób, które uzyskały wyższe wykształcenie.

Rozbieżność ta zarysowuje się wyraźnie w przypadku trzech grup: dziewcząt, dzieci wywodzących się ze środowisk o niskim statusie społecznym oraz należących do mniejszości etnicznych i kulturowych. Odpowiedzialność za to zjawisko przypisywana najczęściej bywa czynnikom społeczno-ekonomicznym, które ograniczają osiągnięcia uczniów i stwarzają bariery utrudniające zdobywanie wykształcenia na miarę pragnień i możliwości. Wskazuje się także na zjawisko urealistycznienia aspiracji, polegające na dopasowywaniu pragnień do możliwości. W miarę przybywania szkolnych doświadczeń, za-

${ }^{14}$ C. Goldenberg i in., Cause or effect? A longitudinal study of immigrant Latino parents' aspirations and expectations, and their children's school performance, American Educational Research Journal, 2001, 38, s. 547-582.

15 D.M. Carpenter II, Expectations, aspirations and achievement among Latino students of immigrant families, Marriage and Family Review, 2008, 43, s. 164-185.

16 C. Goldenberg i in., Cause or effect? s. 547-582.

17 K. Marjoribanks, Family background, adolescents' educational aspirations, and Australian young adults' educational attainment, International Education Journal, 2005, 6, s. 104-112. 
równo dzieci jak i rodzice zdobywają orientację w tym, na co dziecko stać w uczeniu się i co warunkuje jego osiągnięcia. W konsekwencji gromadzenia tej wiedzy młodzi ludzie wybierają takie ścieżki edukacyjne, które stwarzają im realne szanse na zdobycie wykształcenia.

Na tym tle znaczenia nabiera kwestia płci. Powszechnie, także i w naszym kraju, obserwuje się, że dziewczęta mają wyższe aspiracje edukacyjne oraz osiągnięcia w uczeniu się, zaś wyższe pozycje społeczne, bardziej prestiżowe i lepiej płatne zawody są domeną mężczyzn. Przyczyny tych różnic, będących przedmiotem wielu analiz, są złożone, należą do nich stereotypy związane z płcią, niska samoocena związana z seksistowskimi poglądami (np. „dziewczęta są gorsze w matematyce i naukach ścisłych"), czy wczesne podejmowanie ról macierzyńskich i rodzinnych.

Na podstawie licznych badań, których część wyżej przytoczono, można uznać, że tezy o istotnym związku aspiracji rodziców oraz dzieci z osiągnięciami w uczeniu maja stosunkowo silne poparcie empiryczne. Pomimo to parę kwestii budzi wątpliwości, skłaniające do tego, aby relacje te nadal analizować.

W związku z dalekim od jednoznaczności stanem badań, jak również stosunkowo małą liczbą danych dotyczących naszego kraju, pojęto próbę ustalenia zależności pomiędzy aspiracjami edukacyjnymi rodziców i dzieci a ich osiągnięciami w uczeniu się. Ze względu na znaczenie, jakie w przypadku aspiracji ma wykształcenie rodziców, postanowiono sprawdzić, jaką rolę pełni ono w przypadku aspiracji dzieci i ich osiągnięć w uczeniu się.

Badania zrealizowano na ogólnopolskiej próbie rodziców i ich dzieci uczniów klas IV szkół podstawowych $(\mathrm{N}=4931)$. Dane, które były podstawą analiz, pochodzą z szeroko zakrojonych badań nad uwarunkowaniami efektów kształcenia.

Rodzice określali aspiracje dotyczące poziomu wykształcenia dzieci, dzieci zaś w ten sam sposób ustalały swoje aspiracje edukacyjne. Mając do dyspozycji dziewięć poziomów wykształcenia (od podstawowego do wyższego z tytułem naukowym), badani trzykrotnie określali swoje aspiracje. Po pierwsze, zaznaczali maksymalny ich poziom (wykształcenie upragnione, wymarzone), po drugie, ustalali jaki poziom wykształcenia realnie może osiągnąć dziecko (wykształcenie oczekiwane), po trzecie, określali minimalny jego poziom, który skłonni są zaakceptować. Te trzy odmiany aspiracji rodziców i dzieci wzajemnie porównywano, jak też konfrontowano ze wskaźnikami osiągnięć w uczeniu się.

Wskaźnikiem osiągnięć ucznia były oceny dokonywane przez nauczyciela na czterostopniowej skali opisowej: uczeń wyróżniający się, dobry, przeciętny i słaby - oddzielnie dla języka polskiego i matematyki. Pozycjom na tej skali przypisano wartości liczbowe od 5 do 2 , nawiązujące do ocen szkolnych. 


\section{Badania własne}

Aspiracje edukacyjne rodziców są bardzo wysokie, zgodnie z oczekiwaniami najwyższe są aspiracje wymarzone, niższe - realne, zaś najniższe - minimalne możliwe do zaakceptowania. Na poziomie aspiracji maksymalnych $85,46 \%$ rodziców pragnie dla swoich dzieci wykształcenia wyższego, w tym $49 \%$ magisterskiego, a ponad $13 \%$ wyższego ze stopniem co najmniej doktora. Prawie nikt nie zakłada, że dziecko ukończy tylko szkołę podstawową czy gimnazjum, a nawet zasadniczą szkołę zawodową. Tylko 14\% respondentów marzy, aby dziecko ukończyło szkołę średnią, a wśród nich ponad połowa zakłada, że będzie to szkoła pomaturalna.

Aspiracje dzieci w stosunku do swojego wykształcenia są niższe, ale także stosunkowo wysokie. Ponad połowa $(54,7 \%)$ marzy o wykształceniu wyższym, w tym $15,5 \%$ o wyższym ze stopniem co najmniej doktora. Niemniej prawie 5\% uczniów marzy o ukończeniu szkoły podstawowej lub gimnazjum. Niżej oceniają realne szanse zdobycia wykształcenia - tylko 38\% sądzi, że ukończy wyższe studia. Częściej też uznają, że będzie to poziom licencjacki, a nie magisterski. Pozostali jako realne uznają ukończenie szkół średnich $44,4 \%$, w tym prawie połowa pomaturalnych.

Analiza danych wskazuje, że aspiracje rodziców są wyższe niż aspiracje dzieci. Różnice zarysowują się we wszystkich ich odmianach, szczególnie wyraźnie w przypadku maksymalnych. Na przykładzie wykształcenia wyższego widać, że na poziomie aspiracji wymarzonych różnica ta wynosi $35 \%$, realnych - około $25 \%$, zaś minimalnych - tylko $2 \%$. Widoczna jest zatem wyraźna tendencja zmniejszania się różnic.

Dane na temat aspiracji były podstawą analiz mających przynieść odpowiedź na główne pytanie dotyczące ich związków z osiągnięciami. Ze względu na silną korelację ocen nauczycieli (RHO Spearmana wynosi 0,834) przyjęto $\mathrm{w}$ nich jeden wskaźnik osiągnięć ucznia, określony jako nauczycielska ocena ucznia (NOU). Ma on postać średniej ocen z polskiego oraz matematyki i przyjmuje wartości od 2 do 5.

Osiągnięcia dzieci są skorelowane (na poziomie istotności p < 0,001) ze wszystkimi poziomami aspiracji; najsilniej z wymarzonymi i realnymi (RHO Spearmana wynosi 0,37), słabiej z akceptowalnymi $(\mathrm{RHO}=0,22)$. Zależności te mają charakter liniowy - im wyższe osiągnięcia uczniów, tym większe są ich pragnienia dotyczące poziomu wykształcenia. 74\% uczniów wyróżniających się i ponad 50\% uczniów dobrych aspiruje do wykształcenia wyższego, czego pragnie tylko co piąty uczeń słaby. Jedna trzecia słabych uczniów ogranicza swe marzenia do niższych poziomów wykształcenia, z czym mamy do czynienia tylko w przypadku niecałych 3\% uczniów ocenianych jako wyróżniających się (ryc. 1). 


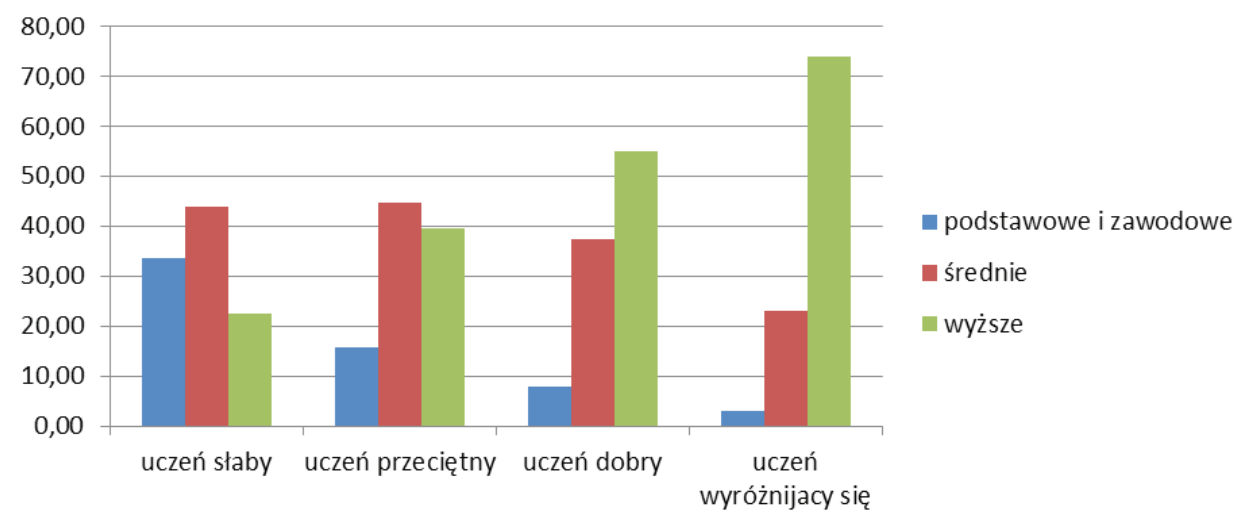

Ryc. 1 Aspiracje wymarzone dzieci a ich osiągnięcia szkolne

Podobne prawidłowości występują w przypadku realnej oceny przyszłego wykształcenia (ryc. 2). Ponad 50\% uczniów wyróżniających się zakłada, że ukończy studia wyższe, a tylko 15\% uczniów słabych oczekuje, że uda im się uzyskać takie wykształcenie. Liczą się z tym, że ich wykształcenie zakończy się na szkole zawodowej lub średniej.

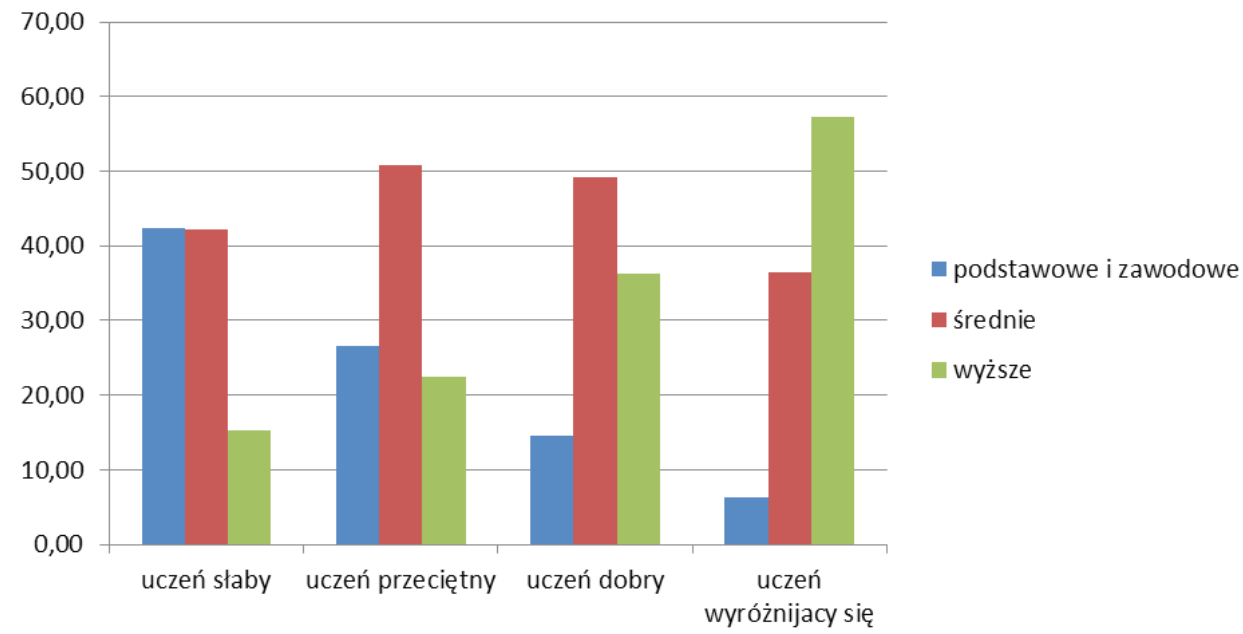

Ryc. 2. Aspiracje akceptowalne dzieci a ich osiągnięcia szkolne 
Aspiracje minimalne są także bardzo wyraźnie związane z osiągnięciami. Im słabsze osiągnięcia, tym częściej uczniowie są skłonni zaakceptować niższe wykształcenie. Trzykrotnie więcej słabych uczniów niż uczniów wyróżniających się akceptuje jego poziom najniższy i odwrotnie - co piąty wyróżniający się uczeń nie akceptuje innego wykształcenia niż wyższe, co występuje tylko w przypadku $8 \%$ uczniów słabych (ryc. 3).

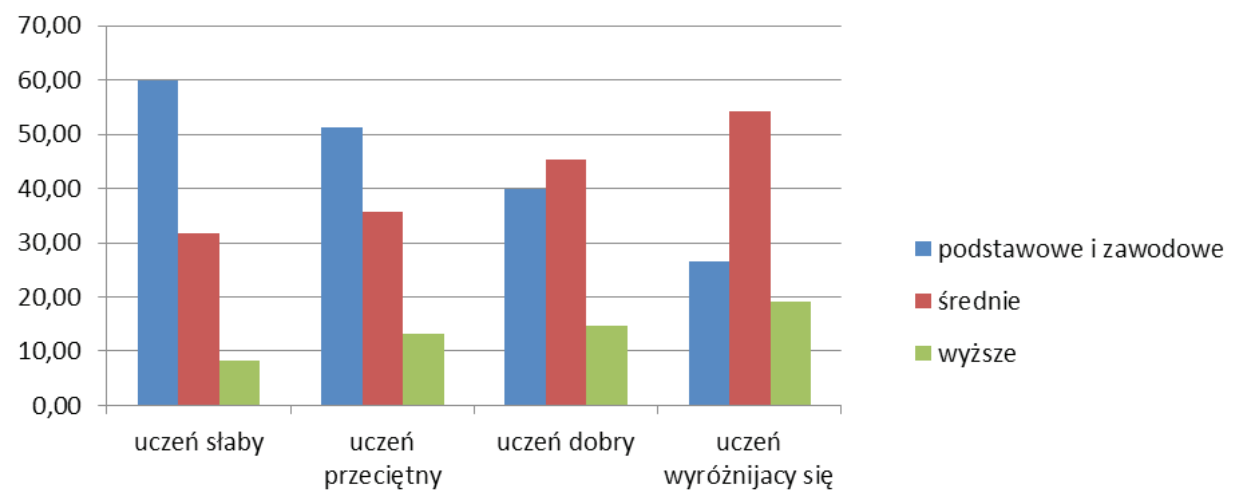

Ryc. 3. Aspiracje realne dzieci a ich osiągnięcia szkolne

Aspiracje edukacyjne rodziców związane są istotnie (na poziomie $\mathrm{p}<$ 0,001) z osiągnięciami ich dzieci. Najsilniejszy związek występuje w przypad$\mathrm{ku}$ aspiracji realnych $(\mathrm{RHO}=0,42)$, a najsłabiej akceptowalnych. $\mathrm{Z}$ danych (ryc. 4) wynika, że zależność pomiędzy aspiracjami rodziców a osiągnięciami

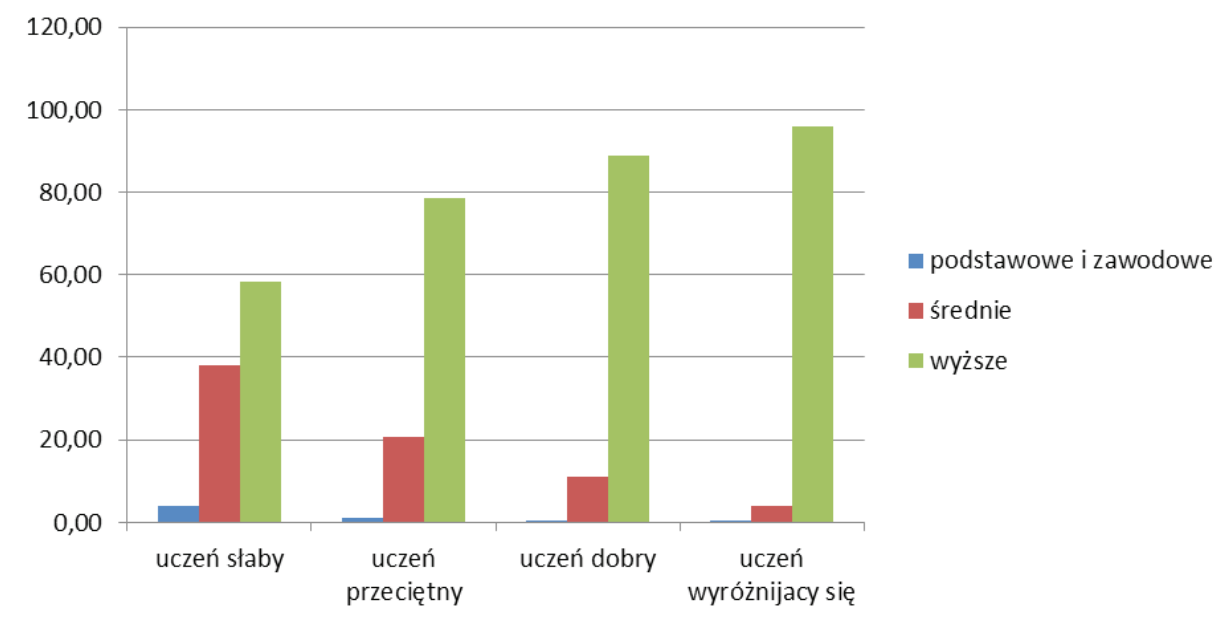

Ryc. 4. Aspiracje wymarzone rodziców a osiągnięcia szkolne dzieci 
jest prostoliniowa. Im lepszym uczniem jest dziecko, tym częściej rodzice pragną dla niego wyższego poziomu wykształcenia. Aspiracje są bardzo wysokie i niemal niezależnie od osiągnięć, gdyż prawie wszyscy rodzice uczniów wyróżniających się i prawie $60 \%$ rodziców uczniów słabych marzy o wyższych studiach dla dziecka.

Rodzice liczą się z tym, że ich pragnienia dotyczące wykształcenia dzieci mogą się nie spełnić, w związku z czym ich oczekiwania są o wiele mniejsze niż marzenia. Jak pokazuje rycina 5, nadzieję na zdobycie przez dziecko wyższego poziomu wykształcenia pokładają głównie rodzice uczniów dobrych i wyróżniających się. Rodzice uczniów przeciętnych i słabych zakładają, że osiągną oni wykształcenie średnie, jednak część z nich dostrzega realne szanse na wyższe wykształcenie dziecka (z taką sytuacją mamy do czynienia u ok. 20\% rodziców słabych uczniów i u ponad 40\% rodziców uczniów przeciętnych).

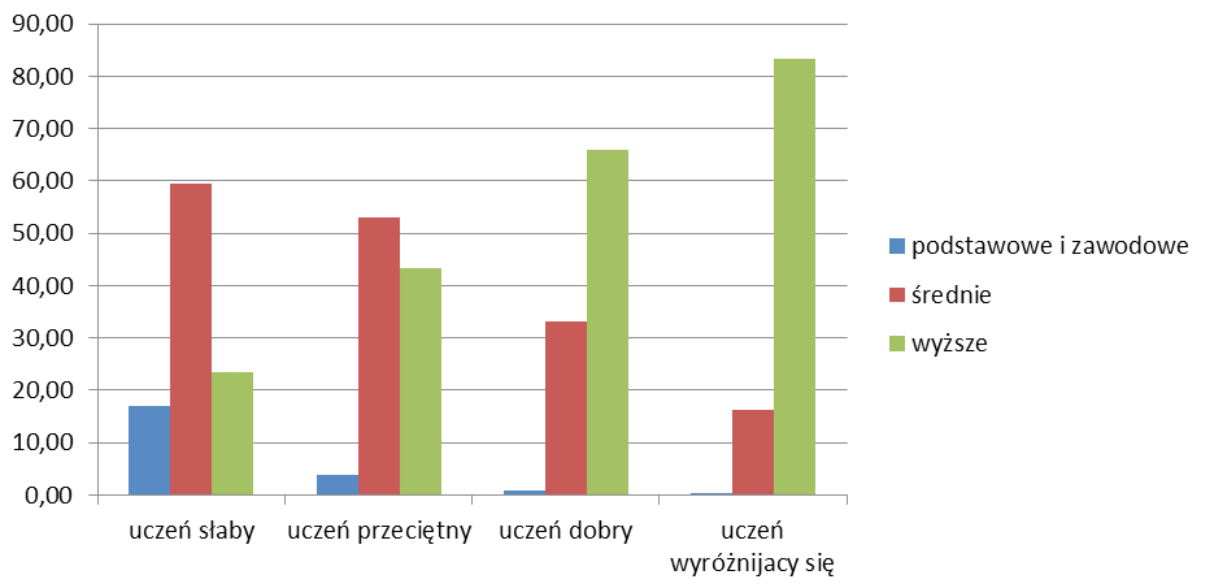

Ryc. 5. Aspiracje realne rodziców a osiągnięcia szkolne dzieci

Ponad 20\% rodziców uczniów wyróżniających sięi 18 \% rodziców uczniów dobrych nie akceptuje innego wykształcenia dziecka niż wyższe. Pozostali zdecydowanie częściej jako minimalne uznają wykształcenie średnie. Im słabsze wyniki w nauce dziecka, tym częściej rodzice są skłonni akceptować najniższy poziom wykształcenia. Prawidłowość ta występuje u prawie połowy rodziców uczniów słabych i blisko $40 \%$ przeciętnych (ryc. 6).

Jak pokazały nasze poprzednie analizy, aspiracje edukacyjne rodziców w silnym stopniu zależą od poziomu wykształcenia: im jest ono wyższe, tym wyższe są aspiracje ${ }^{18}$. Można przypuszczać, że wykształcenie jest także istot-

${ }^{18}$ E. Matczak, W. Kozłowski, Aspiracje edukacyjne rodziców w stosunku do swoich dzieci, Edukacja, 2014, 1, s. 41-54. 
nie związane $\mathrm{z}$ osiągnięciami $\mathrm{w}$ uczeniu się. Otrzymaliśmy wynik zgodny z tym przypuszczeniem: im wyższe wykształcenie mają rodzice, tym lepsze oceny mają ich dzieci. W silniejszym stopniu oceny związane są z wykształceniem matek $(\mathrm{RHO}=0,356)$ niż ojców $(\mathrm{RHO}=0,313)$. Pewne znaczenie ma tu także płeć dziecka; osiągnięcia dziewcząt są mocniej związane z wykształceniem rodziców niż oceny chłopców.

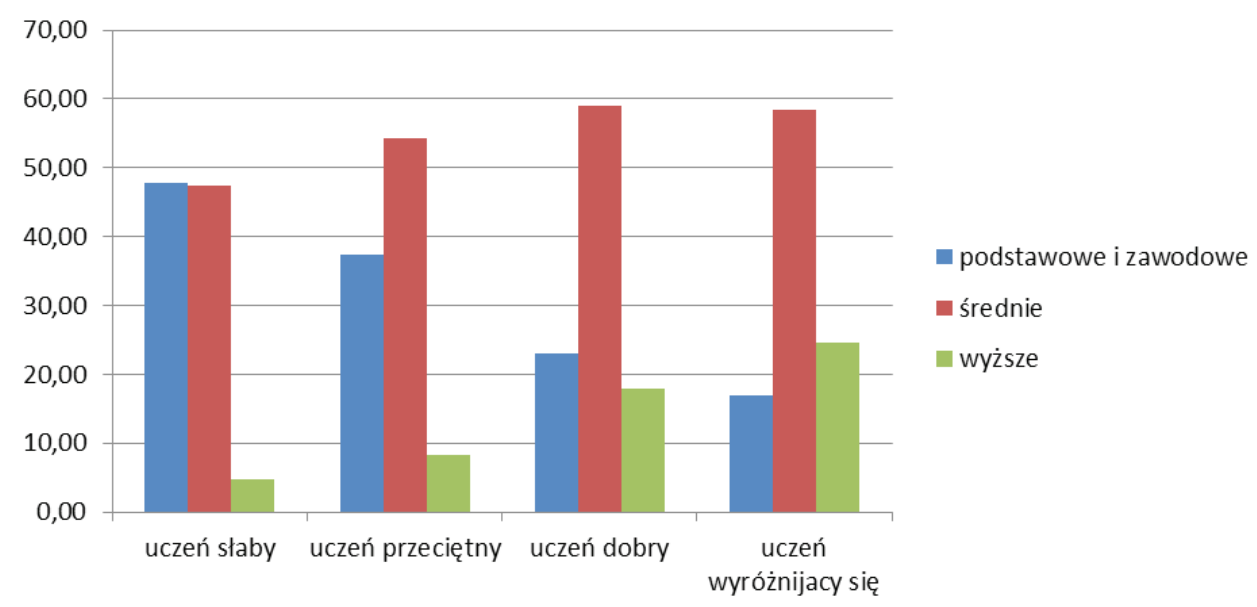

Ryc. 6. Aspiracje akceptowalne rodziców a osiągnięcia szkolne dzieci

Z tego względu należało sprawdzić, czy stwierdzone wyżej zależności pomiędzy aspiracjami a osiągnięciami nie są pozorne - są konsekwencją powiązań tych zmiennych z wykształceniem. Test Cochran-Mantel-Haenszel wykazał, że związek aspiracji edukacyjnych i osiągnięć szkolnych uczniów występuje niezależnie od wykształcenia. Można zatem stwierdzić, że najsilniej z osiągnięciami dzieci związane są realne aspiracje rodziców (V Cramera $=0,333)^{19}$. Z naszych badań wynika, że ta odmiana aspiracji ma również największy wpływ na aspiracje dzieci ${ }^{20}$.

Rodzice mają bardzo duże pragnienia związane z wykształceniem dziecka, w związku z czym kierują się głównie marzeniami. Nie biorą pod uwagę ich osiągnięć, będących wskaźnikiem szkolnych możliwości. Przemawia za tym fakt, iż zdecydowana większość pragnie wykształcenia wyższego niezależnie od osiągnięć dziecka. Dopiero, gdy realnie oceniają szanse edukacyjne, zaczynają brać pod uwagę to, jakie oceny ono uzyskuje. Z tego powodu na poziomie realnym związek aspiracji z osiągnięciami jest najsilniejszy.
19 Tamże.
${ }^{20}$ Tamże. 
Aspiracje realne rodziców mają najsilniejszy wpływ na aspiracje dzieci. Aspiracje dzieci są zdecydowanie niższe niż rodziców, ale bardziej uzależnione od szkolnych sukcesów w nauce; silnie związane są z nimi zarówno marzenia, jak i oczekiwania (RHO odpowiednio 0,283 i 0,272). Najsłabszy związek $\mathrm{z}$ osiągnięciami jest w przypadku aspiracji akceptowalnych (zarówno rodziców jak i dzieci).

\section{Dyskusja}

Zaprezentowane powyżej dane potwierdzają dobrze udokumentowane tezy o związkach aspiracji edukacyjnych z osiągnięciami w uczeniu się. Mówiąc o aspiracjach, ma się na myśli zarówno rodziców, którzy formułują swojej pragnienia i oczekiwania dotyczące dzieci, jak i uczniów także myślących o swej przyszłej edukacji. Na tle innych badań wyżej zaprezentowane charakteryzują się pewną odmiennością.

Większość prac empirycznych analizuje oddzielnie związki aspiracji rodzicielskich i uczniowskich z osiągnięciami, nasza zaś ujmuje jednocześnie obydwa te aspekty. Jak wspomniano we wstępie, duże problemy utrudniające porównywalność wyników badań wiążą się z terminologią, która bywa daleka od jasności i konsekwencji. W pracach amerykańskich używa się zamiennie terminów aspiracje i oczekiwania, te ostatnie zaś odnoszone są nie tylko do poziomu wykształcenia, lecz i osiągnięć dziecka. W badaniach polskich mówi się o aspiracjach oświatowych lub tworzy ogólną kategorię aspiracji, w skład której wchodzą cele życiowe, dążenia w dziedzinie aktywności kulturalnej, rodzinnej, czy społecznej. W pracy niniejszej skoncentrowano się tylko na aspiracjach edukacyjnych (dotyczących poziomu wykształcenia) i wyróżniono ich trzy odmienne rodzaje: maksymalne, realne oraz minimalne możliwe do zaakceptowania. Można przypuścić, że takie podejście pozbawione jest wieloznaczności i nie wzbudza terminologicznych kontrowersji.

Badania aspiracji koncentrują się przeważnie na uczniach szkół ponadpodstawowych, co wydaje się zasadne: mamy wówczas do czynienia z osobami dojrzalszymi, które zaczynają poważniej myśleć o swej przyszłości, ku czemu skłania je konieczność dokonywania wyboru kierunku kształcenia i orientacji zawodowych. W naszym badaniu brali udział uczniowie szkół podstawowych, o których pragnieniach i oczekiwaniach dotyczących przyszłego kształcenia wiadomo znacznie mniej. Także wiedza na temat aspiracji rodziców uczniów w tym wieku jest stosunkowo skromna. Uzyskane wyniki $\mathrm{w}$ pewnym stopniu wzbogacają dostępne dane.

Warunkiem otrzymania odpowiedzi na główne pytanie o zależności pomiędzy aspiracjami rodziców i dzieci a osiągnięciami w uczeniu się było ze- 
branie danych na temat tych aspiracji. Pokazały one, że rodzice, jak i dzieci różnicują aspiracje w trzech odmianach. O ile w przypadku rodziców kwestia ta nie budziła obaw, o tyle w przypadku uczniów nie była ona oczywista. Ze względu na stosukowo młody wiek oraz brak doświadczeń związanych z dokonywaniem wyborów edukacyjnych, dzieci mogły mieć kłopoty z określeniem swoich preferencji. Sygnalizować by je mogła duża liczba braków odpowiedzi, odpowiedzi niezróżnicowane (ten sam poziom wykształcenia we wszystkich trzech przypadkach) lub odpowiedzi niekonsekwentne (zaliczyć do nich można np. wyższy poziom wykształcenia akceptowanego niż maksymalnego, upragnionego). Przypadki takie były rzadkie, co sugeruje, że jednak dzieci w tym wieku potrafią określać swoje aspiracje edukacyjne i brać pod uwagę różne ich odmiany.

Porównanie aspiracji rodziców i dzieci pokazuje, że są one wysokie, zwłaszcza w przypadku rodziców, których większość pragnie dla swych dzieci wyższego wykształcenia. Aspiracje dzieci we wszystkich trzech odmianach są znacznie niższe. Różnicę tę można określić jako lukę aspiracyjną pomiędzy rodzicami i dziećmi. Pomimo występowania tej rozbieżności aspiracje rodziców i dzieci są ze sobą $w$ istotny sposób związane, co sugeruje, że aspiracje są skutecznie przekazywane następnemu pokoleniu w procesie wychowania i socjalizacji (zjawisko to na gruncie socjologii określane jest mianem transmisji).

Na pytanie o związki aspiracji z osiągnięciami w uczeniu się otrzymano spójną, twierdzącą odpowiedź. Zarówno aspiracje rodziców dotyczące dzieci, jak i aspiracje dzieci są w sposób istotny związane z efektami uczenia się. Opierając się na wartościach współczynników korelacji, siłę tych powiązań można określić jako umiarkowaną (zawierającą się w granicach od 0,42 do 0,22). Wielkość współczynników jest jednak zróżnicowana ze względu na rodzaj aspiracji oraz tego, czy odnoszą się one do rodziców czy dzieci. $\mathrm{Z}$ osiągnięciami najsilniej związane są aspiracje realne. Związek ten wyraźnie zaznacza się u rodziców, w mniejszym stopniu u dzieci. Jeśli przyjąć, że otrzymane zależności mogą być podstawą przewidywania osiągnięć w uczeniu się, to w przypadku rodziców prognoz dokonywać należy na podstawie aspiracji realnych, w przypadku dzieci zarówno na podstawie aspiracji realnych, jak i maksymalnych,

Kwestią dyskusyjną jest kryterium osiągnięć w uczeniu się. W naszym badaniu posługiwaliśmy się opiniami nauczycieli na temat poziomu kompetencji uczniów w dwóch przedmiotach: języku polskim oraz matematyce. Wyrażane one były na czteropunktowej skali, zbliżonej do skali ocen. Ponieważ opinie o osiągnięciach w tych przedmiotach były w wysokim stopniu zbieżne, na ich podstawie ustalono zbiorczy wskaźnik, który określono jako opinię o uczniu. 
W stosunku do takiego wskaźnika można mieć oczywiste zastrzeżenie związane z jego subiektywizmem. Przeważnie rolę tę pełnią oceny z wybranych przedmiotów, średnie ocen lub zbiorcze wskaźniki osiągnięć. Rzadziej badacze korzystają z testów osiągnięć szkolnych. Na tym tle opinie nauczycieli mogą sprawiać wrażenie mało wiarygodnych. Wydaje się jednak, że na tym poziomie nauczania mogą trafnie odzwierciedlać wiedzę i kompetencje.

Jak można przypuszczać, opinie o uczniu mają w dużym stopniu charakter intuicyjny. Oparte są na doświadczeniu nauczyciela i stanowią podstawę przeczuć oraz przekonań narzucających się jako oczywiste. Pomimo subiektywizmu i braku uzasadnień intuicja pełni ważną, choć niedocenianą rolę w pomiarze osiągnięć uczniów, na co dawno już zwracał uwagę B. Niemierko ${ }^{21}$.

W trakcie badania dzieci były uczniami klasy czwartej szkoły podstawowej, a więc przeszły pomyślnie okres nauczania początkowego. W pierwszych trzech klasach wymagania w stosunku do uczniów nie są zbyt wygórowane: nie akcentuje się zbyt mocno treściowych odrębności pomiędzy przedmiotami, a oceny postępów w uczeniu się mają charakter opisowy. Wyrażając swoje opinie, nauczyciele przypuszczalnie opierali się na doświadczeniach i obserwacjach z tego wczesnego okresu, które mogą być trafnym odzwierciedleniem postępów w uczeniu się. Zadanie, jakie przed nimi postawiono, odwoływało się do tych uogólnionych i mało zróżnicowanych doświadczeń, które odpowiadają specyfice początkowego nauczania. W tym względzie otrzymane od nich dane mogą odznaczać się znaczną wiarygodnością.

Uwzględnienie trzech odmian aspiracji pozwoliło uchwycić zróżnicowania ich zależności z osiągnięciami, co umyka uwadze badaczy posługujących się jedną ich odmianą. Jak można zakładać, aspiracje maksymalne są wyrazem pragnień i marzeń, na minimalne zaś duży wpływ mają lęki i obawy.

Nie negując znaczenia emocji, można przyjąć, że działania rodziców sprzyjające edukacji dziecka, jak również motywacja i zaangażowanie dziecka w uczenie się wyznaczane są głównie przez to, na co realnie mają oni wpływ i co leży w zakresie ich możliwości.

W przypadku uczniów równie duże znaczenie mogą mieć marzenia o wykształceniu, czyli ich osiągnięcia mogą pozostawać pod wpływem nadziei.

Dominujące znaczenie aspiracji realnych $\mathrm{w}$ kontekście osiągnięć nie jest zaskakujące, jednak może być pomocne $\mathrm{w}$ wyjaśnianiu efektów przeprowadzonych dotychczas badań. Jak sugerował ich przegląd zawarty we wprowadzeniu, silniejsze są związki osiągnięć z oczekiwaniami niż aspiracjami, zwłaszcza oczekiwaniami dotyczącymi przebiegu i efektów uczenia się. W zaprezentowanym badaniu nie braliśmy pod uwagę oczekiwań rozumia-

${ }^{21}$ B. Niemierko, Rola intuicji w pomiarze osiagnięć uczniów, Edukacja, 1983, 2, s. 38-54. 
nych jako przewidywania dotyczące efektów uczenia się. Jeśli jednak przyjąć, że aspiracje realne zbliżone są do oczekiwań związanych z tym poziomem wykształcenia, jaki może osiągnąć dziecko, to zarysowuje się możliwość porównań otrzymanych przez nas rezultatów z pracami innych autorów. Zestawienie takie pokazuje dużą zbieżność wyników: silniejsze związki osiągnięć $\mathrm{z}$ aspiracjami realnymi, będącymi odpowiednikiem oczekiwań, niż z aspiracjami maksymalnymi, będącymi wyrazem marzeń i pragnień.

Wśród wielu czynników warunkujących aspiracje edukacyjne duże znaczenie przypisuje się statusowi społeczno-ekonomicznemu (SES) oraz kapitałowi społecznemu. W naszym badaniu kontrolowaliśmy tylko jeden element wchodzący w skład tych zmiennych, a mianowicie wykształcenie rodziców. Znaczenie tego czynnika pokazuje wiele badań. Na przykład, Gill i Reynolds stwierdzili, że wykształcenie rodziców jest najsilniejszym predyktorem ich edukacyjnych oczekiwań w stosunku do dzieci, przewyższając w tym względzie znaczenie innych zmiennych, takich jak płeć dziecka, wielkość rodziny i otrzymywane przez nią wsparcie finansowe ${ }^{22}$. Davis-Kean doszedł do wniosku, że poziom wykształcenia rodzica pozwala lepiej przewidywać ich oczekiwania dotyczące edukacji dzieci niż dochody rodziny ${ }^{23}$. Jak ustalili Englund i inni, na podstawie wykształcenia matek, niezależnie od ich poziomu inteligencji, można trafnie przewidywać osiągnięcia ich dzieci w początkowym okresie kształcenia ${ }^{24}$.

$\mathrm{Z}$ naszych poprzednich analiz wynika, że poziom wykształcenia w najsilniejszym stopniu określa aspiracje edukacyjne rodziców ${ }^{25}$. Zależność ma charakter liniowy: im wyższe wykształcenie ma rodzic, tym wyższe są pragnienia i oczekiwania dotyczące wykształcenia własnego dziecka. Niniejsze badanie pozwoliło $\mathrm{w}$ analogiczny sposób określić rolę wykształcenia rodziców w odniesieniu do aspiracji dzieci oraz ich osiągnięć. Otrzymane wyniki potwierdziły znaczenie tego wyznacznika pozycji społecznej: poziom wykształcenia w silny sposób związany jest zarówno z aspiracjami dzieci, jak i ich osiągnięciami. Podobnie jak w poprzednich badaniach, otrzymane zależności zbliżone są do liniowych. Dane te są zgodne z tendencjami obserwowanymi od kilkudziesięciu lat w badaniach socjologicznych i stanowią silny dowód na rzecz zjawiska „dziedziczenia” wykształcenia przez kolejne

${ }^{22}$ S. Gill, A.J. Reynolds, Educational expectations and school achievement of urban African American children, Journal of School Psychology, 1999, 37, s. 403-424.

${ }^{23}$ P. Davis-Kean, The influence of parent education and family income on child achievement: The indirect role of parental expectations and the home environment, Journal of Family Psychology, 2005, 19, s. 294-304.

${ }^{24}$ M.M. Englund i in., Children's achievement in early elementary school: Longitudinal effects of parental involvement, expectations, and quality of assistance, Journal of Educational Psychology, 2004, 96, s. 723-730.

${ }^{25}$ W. Kozłowski, E. Matczak, Aspiracje edukacyjne rodziców, s. 66-78. 
pokolenia Polaków. Pozwalają także przewidywać dalszy wzrost poziomu wykształcenia naszego społeczeństwa w związku z wyraźnie rosnącą proporcją osób legitymujących się jego wysokim poziomem.

Zaprezentowane badania nie zawierają danych, które pozwalałyby na wskazanie kierunku zależności pomiędzy aspiracjami a osiągnięciami dzieci. Większość prac w sposób otwarty lub niejawny główną rolę przypisuje aspiracjom rodziców. To ich pragnienia i dążenia, którym towarzyszą oddziaływania na dziecko i wspieranie jego edukacji, określają aspiracje dzieci oraz szkolną karierę. Nie można jednak wykluczyć wpływu, jaki na aspiracje rodziców mogą mieć osiągnięcia dzieci, będące ważną informacją na temat ich zdolności, motywacji do nauki, czy zainteresowań. W związku z taką możliwością nasuwa się przypuszczenie o wzajemnym, dwustronnym oddziaływaniu na siebie aspiracji i osiągnięć. Próby empiryczne sprawdzające tę hipotezę nie należą do licznych, a czasami przynoszą negatywne efekty, co jednak nie powinno zniechęcać do dalszych analiz ${ }^{26}$.

\section{BIBLIOGRAFIA}

Bandura A., Barbaranelli A., Caprara G.V., Pastorelli C., Mechanism of moral disengagement in the exercise of moral agency, Journal of Personality and Social Psychology, 1996, 71.

Benner A.D., Mistry R.S., Congruence of mother and teacher educational expectations and low-income youth's academic competence, Journal of Educational Psychology, 2007, 1.

Carpenter II D.M., Expectations, aspirations and achievement among Latino students of immigrant families, Marriage and Family Review, 2008, 43.

Catsambis S., Expanding knowledge of parental involvement in children's secondary education: connections with high schools seniors' academic success, Social Psychology of Education, 2001, 5.

Davis-Kean P., The influence of parent education and family income on child achievement: The indirect role of parental expectations and the home environment, Journal of Family Psychology, 2005, 19.

Cheng S., Starks B., Racial differences in the effects of significant others on students' educational expectations, Sociology of Education, 2002, 75.

Englund M.M., Luckner A.E., Whaley G.J., Egeland B., Children's achievement in early elementary school: Longitudinal effects of parental involvement, expectations, and quality of assistance, Journal of Educational Psychology, 2004, 96.

Fan X., Chen M., Parental involvement and students' academic achievement: A meta analysis, Educational Psychology Review, 2001, 13.

Flouri E., Raising expectations, The Psychologist, 2006, 19(11).

Gill S., Reynolds A.J., Educational expectations and school achievement of urban African American children, Journal of School Psychology, 1999, 37.

Goldenberg C., Gallimore R., Reese L., Garnier H., Cause or effect? A longitudinal study of immigrant Latino parents' aspirations and expectations, and their children's school performance, American Educational Research Journal, 2001, 38.

\footnotetext{
${ }^{26}$ C. Goldenberg i in., Cause or effect? s. 547-582.
} 
Goodman A., Gregg P., Washbrook E., Children's educational attainment and the aspirations, attitudes and behaviours of parents and children through childhood in the UK, Longitudinal and Life Course Studies, 2011, 2.

Goyette K., Xie Y., Educational expectations of Asian American youths: Determinants and ethnic differences, Sociology of Education, 1999, 72.

Halle T.G., Kurtz-Costes B., Mahoney J.L., Family influences on school achievement in low-income, African American children, Journal of Educational Psychology, 1997, 89.

Hossler D., Stage F.K., Family and high school experience influences on the postsecondary educational plans of ninth-grade students, American Educational Research Journal, 1992, 29.

Jacobs N., Harvey D., Do parents make a difference to children's academic achievement? Differences between parents of higher and lower achieving students, Educational Studies, 2005, 31.

Janowski A., Aspiracje młodzieży szkót średnich, PWN, Warszawa 1997.

Jodl K.M., Michael A., Malanchuk O., Eccles J.S., Sameroff A., Parents' roles in shaping early adolescents' occupational aspirations, Child Development, 2001, 72.

Juang L., Silbereisen R.K., The relationship between adolescent academic capability beliefs, parenting, and school grades, Journal of Adolescence, 2002, 25.

Khoo S., Ainley J., Attitudes, intentions and participation, LSAY research report 41, Australian Council for Educational Research, Melbourne 2005.

Kozłowski W., Matczak E., Aspiracje edukacyjne rodziców w stosunku do swoich dzieci, Edukacja, 2014, 1.

Lara-Alecio, Rafael I.J.B., Ebener R., Developing academically supportive behaviors among Hispanic parents: What elementary teachers and administrators can do, Preventing School Failure, 1997, 42.

Lewowicki T., Aspiracje dzieci i młodzieży, PWN, Warszawa 1987.

Ma X., Participation in advanced mathematics: Do expectation and influence of students, peers, teachers, and parents really matter? Contemporary Educational Psychology, 2001, 26.

Matczak E., Kozłowski W., Aspiracje edukacyjne rodziców, Ruch Pedagogiczny, 2012, 1.

Marjoribanks K., Family background, adolescents' educational aspirations, and Australian young adults' educational attainment, International Education Journal, 2005, 6.

Mau W., Educational planning and academic achievement of middle school students: A racial and cultural comparison, Journal of Counseling and Development, 1995, 73.

Neuenschwander M.P., Vida M., Garrett J.L., Eccles J.S., Parents'expectations and students' achievement in two western nations, International Journal of Behavioral Development, $2007,31$.

Niemierko B., Rola intuicji w pomiarze osiagnięć uczniów, Edukacja, 1983, 2.

Singh K., Bickley P.G., Trivette P., Keith P.B., Anderson E., The effects of four components of parental involvement on eighth-grade student achievement: Structural analysis of NELS-88 data, School Psychology Review, 1995, 24.

Seyfried S.F., Chung I., Parent involvement as parental monitoring of student motivation and parent expectations predicting later achievement among African American and European American middle school age students, Social Work with Multicultural Youth, 2002, 11.

Strand S., Minority ethnic pupils in the longitudinal study of young people in England (LSYPE), Department of Children, Schools, and Families: 2007, Research Report 002.

Trusty J., Plata M., Salazar C.F., Modeling Mexican Americans' educational expectations: Longitudinal effects of variables across adolescence, Journal of Adolescent Research, 2003, 18.

Zhan M., Assets, parental expectations and involvement, and children's educational performance, Children and Youth Services Review, 2006, 28. 